\title{
11. 24 and Torture
}

Bev Clucas ${ }^{*}$

\section{A. Introduction}

In contrast to the majority of the papers in this collection, this chapter does not examine the permissibility of torture or deal with one of the other more frequent angles on the topic. Instead, I consider the portrayal of torture as an element of entertainment in the Emmy-award winning television series 24 and pose the question whether 24's depiction of torture crosses the boundary between mere entertainment and propaganda.

Many of us are familiar with 24 , the phenomenally popular series from the US, the seventh season of which is due to be aired in January 2009. The formula of each season is the same: 24 hours pass 'in real-time', as we follow the adventures of the protagonists, mainly personnel of a fictional body located in Los Angeles, CTU (Counter-Terrorism Unit). Principal among the characters of the show is Jack Bauer, its hero. Each 24 hours (i.e. 24 episodes) is devoted to defeating some evil terrorist person or group. In each series, people are tortured or killed, in pursuit of a higher goal.

The programme makes repeated use of a device called the 'ticking time bomb' scenario: the good guy has in his power a terrorist or suspected terrorist, against the backdrop of an imminent threat (for example, in 24's case, nuclear bombs or biological weapons), which would have, if fulfilled, catastrophic consequences for innocent people. The terrorist refuses to talk - but the hero is convinced that if only he can persuade the suspect to spill the beans, this major catastrophe will be averted. Time is desperately short, so 'persuasion' (if any) quickly turns into a form of torture. In 24, torture is almost invariably successful as a means of extracting information, which ultimately does prevent the threatened disaster. The only exception to this rule is found in the character of Jack Bauer, who never capitulates, no matter how hard he is pressed.

Despite, or perhaps because of its popular and commercial success, particularly in the context of the US and UK War on Terror and abuse of prisoners in Abu Ghraib, a groundswell of concern about 24 has started to be heard. There is disquiet about the number of torture scenes on television, particularly since 9/11. The Parents' Television Council has crowned 24 as the worst offender. ${ }^{1}$ Many people decry the inaccuracies about torture that are promulgated by the show. There is unease about

With grateful thanks to all who contributed to the gestation of this paper, particularly Suzanne Uniacke and Christian Twigg-Flesner.

1 J. Shirlen, 'Worst TV Show of the Week'. Available online: <http:/www.parentstvorg/ PTC/publications/bw/2007/0125worst.asp> (accessed 25 July 2008). 
the effect the show may be having on real soldiers' interrogation techniques. ${ }^{2}$ Others wonder whether 24 has a persuasive effect that works against the US and its allies their enemies might themselves be more inclined to believe that torture is widespread amongst Western soldiers, and therefore feel themselves justified in violent action against US and UK soldiers and civilians.

In this chapter, I explore and reflect on the underlying themes concerning torture and legitimate action in 24. I begin with a short introduction to the TV show itself, highlighting the many different instances of torture, as well as some of the general criticsms levelled at it. I then proceed to consider some of the moral issues associated with the dissemination of information about torture in general, first in relation to factual instances of torture, and then fictional. This discussion informs a more detailed analysis of the depiction of torture in 24 . Having considered the express intentions of the programme makers, I apply a scheme of analysis on 'speech acts' devised by J.L.Austin, and developed by Langton, to argue that the real intention of the programme makers is better understood as pro-torture propaganda: an instance of double immorality, as not only does the show push a protorture message, but also, it does so under the pretense of pure entertainment.

\section{B. The show}

The series began in 2001, making it broadly contemporaneous with $9 / 11$. The unique selling point of the show is that all the action takes place 'in real-time'. Each hour of an episode on television accounts for an hour in the life of the show. Even breaks for adverts count towards time elapsed. As the action of each series takes part within one 24-hour period, there is urgency to the drama on the screen, which is augmented by the recurrent interpolation of a digital clock, and frequent use of split-screens, enabling the viewer to see the simultaneous activities of different characters.

The good guys of the series, by and large, are the staff of CTU and the American Administration. It is CTU's task to prevent or frustrate threatened terrorist attacks.

The prevention of terrorism requires intelligence. And in 24, the necessary information is almost always obtained by torture. Unusually, at least at the time the programme was first aired, torture is done just as much by the good people as the bad - if not more.

The types of torture I have viewed on the show include, but are not limited to, the following: ${ }^{3}$

- Hanging a person on hooks

- the application of hot scalpels to the body

2 See below.

3 References to specific seasons and episodes where these particular instances occur have not been included for the sake of concision. All are taken from seasons 1-6. 
- the application of a sanding machine to the body

- beating someone up or other physical violence

- targeted physical harm (e.g. the bundle of nerves on the shoulder) intended to cause the maximum possible pain

- $\quad$ aggravation of wounds with caustic liquid

- $\quad$ pharmaceutical torture - injections to cause pain (hyocine-pentothal)

- removing the tip of someone's finger with a cigar cutter

- threats to shoot

- breaking a suspect's fingers

- using a power drill on someone's shoulder

- threats with a knife

- shooting a suspect in the leg and threatening to shoot the other one if the information is not revealed

- non-specific threats to 'do anything to get answers'

- threats to kill a loved one

- electric shocks (including at the order of the President)

- electrocution using a hotel lamp

- shocks by taser

- denial of painkillers to someone suffering from a bullet wound

- psychological torture in the form of a fake execution of the wife and children of a terrorist.

Howard Gordon, one of the show's writers who invents many of the torture scenes, describes them as 'improvisations in sadism'. ${ }^{4}$ Their source material includes CIA interrogation manuals, but the scenes in the programme are mainly the result of writers' imagination. However, Gordon admits that 'the truth is, there is a certain amount of fatigue. It's getting harder not to repeat the same torture techniques over and over'. ${ }^{2}$

Perhaps 24 is nothing more than a phenomenally successful TV show with a nasty imagination. But various people have been raising concerns about the effects of the show.

\section{Effects of the show}

In 2006, there was a visit by US Army Brigadier General Patrick Finnegan, Dean of the United States Military Academy at West point, to meet the creative team of 24.

4 J. Mayer, 'Whatever it takes: the politics of the man behind '24'" The New Yorker 19 February 2007, p. 3. Available online:

$<$ http://www.newyorker.com/reporting/2007/02/19/070219 fa_fact_mayer?printable=true> (accessed 11 July 2008) Ibid. 
Also accompanying him were persons described as three 'of the most experienced military and FBI interrogators in the country'. ${ }^{6}$ This delegation had come to express their concerns about what they saw as the primary political and moral messages of the show - that protection against torture under American law must practically, and morally ought to be, surrendered, in order to preserve security. Apparently, the immoral and illegal behaviour endorsed by the show had already had a negative effect on real American soldiers in training. ${ }^{7}$ To this, Philippe Sands adds a description of the way in which 24 provided both the inspiration for interrogation techniques $^{8}$ and '[c]ultural sensitisation... that normalised violence and justify aggression. ${ }^{9}$

Other concerns have been raised about the nature of the entertainment in 24 , as well as this allegedly corrosive effect on the minds and methods of US soldiers. One criticism is that the ticking time bomb scenario hardly (if ever) happens in real life, and that by perpetually presenting this plot device as the case where torture is acceptable or even required, those watching the show become more inclined to accept the permissibility of torture in other cases. ${ }^{10}$ And, an important point stressed by real-life interrogators is that torture is not effective - it does not yield reliable information. Yet shows such as 24 send the message that the essential and correct information obtained by torture is what justifies the torture in the first place. ${ }^{11}$

\section{B. Are bad consequences the only measure?}

These consequences, if they do indeed result from the broadcast of shows such as 24 , are alarming and arguably immoral. But consequences are easy to presume and predict, and hard to prove.

In any case, to focus on consequences, on teleological theories as a measure of rights and wrongs (what is morally right or wrong depends on the consequences) is to ignore another important, in my opinion more important, type of moral theory: the type of standpoint from which people have rights and duties, and actions are morally permissible or impermissible, independently of potential consequences - for example in Immanuel Kant's categorical imperative. This latter type of

6 Ibid.

7 Ibid., pp. 3-4.

8 P. Sands, Torture Team: Deception, Cruelty and the Compromise of Law (London, Penguin, 2008) pp. 73-4.

9 Ibid., p. 272.

10 See Association for the Prevention of Torture, Defusing the Ticking Bomb Scenario: why we must say No to torture, Always (Geneva, The Association for the Prevention of Torture, 2007). Available online:

http://www.apt.ch/index.php?searchword=defusing\&option=com_search\&Itemid=5 (accessed 8 August 2008)

11 See below. 
position/stance might argue that shows such as 24 are immoral irrespective of whether or not they cause bad consequences.

For the purposes of this chapter, I assume that torture is categorically impermissible in principle (i.e. independently of consequences). ${ }^{12}$ Instead, my focus is on this question: if we accept, for the sake of argument, that torture is categorically prohibited, what significance does this acceptance have for our evaluation of 24 ? What conclusions ought we to draw about the moral nature of the particular representations of torture in 24 , or the moral status of a television programme that utilizes torture as an aid to dramatic tension?

Before considering these issues, I take a step back to think about the dissemination of images of or portrayal of torture in general.

\section{Disseminating torture 'information'- factual and fictional}

Information about torture, including allusions to, descriptions or depictions of, and discussions about torture ('information' for short, as an admittedly clumsy shorthand), seems at least capable of being morally neutral in itself. Information may be put to moral use (preventing torture) or immoral use (e.g. the instigation of torture, the encouragement of torture, and the failure to prevent torture). In this view (of at least the neutrality of information about torture), I differ from my colleague, Massimo La Torre, who in his chapter takes the position that even to discuss torture is morally wrong, unless the intention of the discussants is to combat arguments in favour of torture (in which case it is the lesser of two evils). ${ }^{13}$

Whether or not 'information' about torture is real (for example in Abu Ghraib) or fictional (24), it is useful to distinguish three sets of circumstances, which will assist in determining the moral status of the publication:

1. the intention or motive of the publisher/broadcaster/disseminator/author (I use the term 'publisher' and 'publication' to cover all of these possible scenarios);

2. the consequences of the publication (broadcast/dissemination/etc), measured by some moral standard;

3. the intention or motive of the recipient (viewer/listener/reader) of the broadcast.

13 Chapter 1 above. 


\section{Actual torture}

First, I consider these three sets of circumstances in the context of information dissemination about real torture.

\section{Intention of the publisher}

Where the intention of the publisher is to use this information for a morally good purpose, e.g. exposure in order to prevent continuation of the practice, then publication is morally required. (And where someone has knowledge of real torture, it is a least a prima facie moral duty to make this public, not just in order to rescue the victims, but in order that other agents may use this information to guide their choices (e.g. to protest; to lobby against torture; to vote against a government which supports torture)).

\section{Consequences of the publication}

Even if we assume that the publication of information about real torture is prima facie morally required, there might be thought to be two possible sets of consequences (not the result of any intervening action) that outweigh this prima facie obligation: direct and indirect consequences.

\section{a) Direct}

In some circumstances, it might be argued that publication causes a further direct wrong (e.g. a further violation of the rights or dignity or privacy of the person or group against whom the torture was committed). In my view, any such violation could be avoided by obtaining the consent of the person or group involved, or by maintaining anonymity. But even if it were arguable that a violation still persists, any such injustice might be thought to be outweighed by the prevention of more serious wrong (i.e. the continuation of torture; failure to bring a torturer to justice, etc).

\section{b) Indirect}

It might be thought that some pernicious, indirect consequences may flow from the publication of information about torture. On occasion, it is argued that, even where 
activities are not impermissible in themselves, they ought to be prohibited because they make illegitimate activities more likely in various ways. ${ }^{14}$ These types of argument come under the umbrella of 'slippery slope' arguments. For example, perhaps it is feared that making it known that torture does in fact occur, or making known the ways in which it occurs, makes it more likely that bad people will use torture in the future, or will give someone inspiration about how best to go about torturing a victim. Or perhaps it is feared that the sight of scenes of torture causes psychological damage to the viewer. Could the force of the slippery slope argument require suppression of factual information?

My answer is a cautious 'perhaps', but this case would need to be made out in full. Beyleveld and Brownsword put it this way, in the context of human dignity:

$[\mathrm{T}]$ hose who argue that intrinsically acceptable activities are unacceptable because they make it impossible effectively to prohibit activities that are contrary to human dignity need to establish their case. This is no easy matter, once it is appreciated that the endpoint 'failure effectively to prohibit activities contrary to human dignity' cannot be broadly defined - e.g. so that it is satisfied by the mere possibility of or even the actual doing of things contrary to human dignity by a limited number of individuals. If such an endpoint is acceptable, and if we accept the argument against cloning of sheep then, in consistency, we must argue that any technological development (or research into it) that provides the means to carry out activities that violate human dignity that ought to be prohibited ought itself to be prohibited. Thus, for example, we should argue that the construction of the printing press (and research and technology that made this possible) should have been prevented, because, for example, the printing press would provide the means for the dissemination of racist propaganda that could (and would, one day, somewhere) be used to aid and abet policies of genocide that are contrary to human dignity. But this logically requires us to argue that all technology, even Stone Age technology and fire-making, should have been prohibited, because such technology could, and would, be used for evil purposes. And it cannot be stopped here; for human beings have, without employing any technology, through using what exists in nature, and by the use of their bare hands, the means to steal, rape, and murder, etc. Hence, accepting this argument requires us to accept that human beings ought to be prohibited. In effect, the view that human beings ought not to exist because they have the ability to eat from the tree of knowledge is implicit in the use of a broad endpoint in slippery slope arguments based on empirical claims. ${ }^{15}$

We can apply this analogously to torture. Thus, the indirect consequences are not the responsibility of the publisher, unless and until there is clear evidence that the specific 'slippery slope' scenario is being brought about (e.g. watching news reports about torture invariably causes the majority of viewers to behave with more violence towards other agents than they would have otherwise).

14 D. Beyleveld and R. Brownsword, Human Dignity in Bioethics and Biolaw (Oxford, Oxford University Press, 2001), p. 166 and S. D. Pattinson, 'Regulating Germ-Line Gene Therapy to Avoid Sliding Down the Slippery Slope' Medical Law International 4, nos. 3-4 (2000): 213222.

Beyleveld and Brownsword, Human Dignity, p. 167. 
Where the publication or dissemination of information about torture is morally permissible or required, I would suggest that (fear of) any immoral intention or motive on the part of the recipient does not make the publication immoral. One practical example might be the exposure of the abuses at Abu Ghraib, and the concern that this would invite retaliation (allegedly the impetus for the beheading of US civilian Nick Berg). ${ }^{16}$ The wrongdoing is an intervening act which is not the responsibility of the publisher. Many good or neutral things can be put to evil use (e.g. using a pencil to stab someone in the eye), but this does not mean that we should prohibit the thing itself; rather we should attempt to prevent wrongdoing and punish wrongdoers.

To conclude: where the publication of factual information is morally neutral or morally required, I suggest that only a specific and established slippery slope evil ought to override the promulgation of that which is at least morally neutral.

\section{Fictional torture}

Perhaps we can agree that torture is wrong. We might even agree that torture is absolutely wrong, even where the goal is to save other persons' lives. We might agree that my diagnosis of the moral import of the three circumstances which I have just discussed in respect of real torture.

If the torture scenes depicted in 24 were real, this television show would depict heinously wrong actions, without any noble purpose such as exposure, and without any attempt to bring those responsible for the torture to justice. However, 24 is fiction; entertainment; what's the harm in that?

Entertainment need not be 'mere entertainment'. Educational films, for example, provide a means of disseminating information in a context which is palatable for the viewer. Art of various kinds - whether painting, film, or literature - can prompt the viewer or reader to think, to question, to take part in an ethical enterprise, or at least to discover, in Milan Kundera's words, 'the various dimensions of existence'. ${ }^{17}$ These instances will all seem to fall within the category where the intention or motive of the publisher is good. And, as discussed earlier, I suggest that where publication is morally neutral or morally good, only a specific and established slippery slope evil ought to override the promulgation of that which is morally neutral.

Popular television programmes, although not part of the high culture that we normally think of as providing a doorway to the ethical world - what Roger Scruton

16 B. Branford, "Berg father "had to let son go"'. Available online: < http://news.bbc.co.uk/ 1/hi/world/americas/3853607.stm> (accessed 25 July 2008).

17 M. Kundera, The Art of the Novel (rev. ed., London, Faber and Faber, 2005), p. 5. 
calls 'the secular path to the ethical life...which teaches us to live as if our lives mattered eternally', ${ }^{18}$ need not be excluded, surely, from categories of fiction which may have morally good or morally neutral status. In March 2000 the soap opera Hollyoaks broadcast an episode in which a young man was raped by a group of youths, aiming to raise awareness of the fact that rape is not simply a wrong that is practised against women. ${ }^{19}$ Perhaps some perverted individuals were titillated by in this, but I do not think, if this was the case, that the intervening acts or motives of the recipient of the broadcast detract from the morally good aim of the programme.

According to the scheme outlined above, the depiction of torture may be permissible where the intention of the publisher is not immoral, and the publication neither causes direct harm nor leads to a demonstrable 'slippery slope' situation. This would tend to suggest that fictional TV series which include scenes of torture may be broadcast, so long as they avoid harm. However, the assumption that a programme with the express intention of entertainment is not immoral requires further investigation.

\section{The morality of 24}

In the case of 24 , has the series stepped out of the category of programmes which we might accept as pure entertainment? Is it arguable that there is some other, discernable, implicit message $?^{20}$ If so, might this change our view of the legitimacy or moral permissibility of the intention of the publisher? In order to address this question, I consider the quantity of torture in the programme; the portrayal of torture as a necessary and valuable means of extracting information; the dodging of questions regarding legal permissibility; the clear implication that heroes torture as part of their duty; the suggestion that torture does not have serious physical or psychological consequences for the victim; the role of the repeated 'ticking time bomb' scenario providing support for the necessity of torture; and the lack of any convincing dramatic challenge to these points.

19 BBC News, 'The Drama and Crisis of Soaps'. Available online: $<$ http://news.bbc.co.uk/ 1/hi/entertainment/tv_and_radio/1574982.stm $>$ (accessed 25 July 2008).

20 At various points during the gestation of this chapter, I worried that I might have set myself the mammoth task of pronouncing on the moral status of all films, TV series, and books, containing violence that lacked an overarching moral, educational, purpose. I'm thinking in particular about films such as the Terminator, or Steven Segal movies with their high violence and body counts. But I do not think it is necessary, for this paper, to come to any verdict on this type of entertainment, though this is a very important question. (Though we should not forget that even if such programmes are morally permissible in themselves, they arguably ought to be prohibited if a serious slippery slope case can be made out.) 


\section{The quantity of torture}

The Parents' Television Council, a non-partisan watchdog group, reports that the first five seasons of 24 (120 hours' of viewing) contained 67 torture scenes - 1 torture scene per 1.8 episodes, or an average of 13 per series. The New Yorker reports that Melissa Caldwell, the Council's senior director of programmes, said, '24 is the worst offender on television: the most frequent, most graphic, and the leader in the trend of showing the protagonists using torture'. ${ }^{21}$

I counted a similar prevalence of torture in season six -13 scenes or types of torture. In so counting, I restricted myself to instances where physical or psychological distress was inflicted in order to force one of the characters to reveal information (e.g. the location of the remaining nuclear bombs), or perform an action under time pressure (e.g. programme a trigger for the remaining nuclear bombs). These were in addition to various other instances of threat, blackmail, beatings, shootings, and killings.

We tend to think that frequency has some correlation with an agent's attitude towards something. A man who once, in an unusual state of emotional distress, lashes out and hits his wife, is not necessarily branded a perpetrator of domestic violence (which implies a person who believes it is permissible to behave violently, in this case towards women). However, the husband of a woman who ends up in hospital on multiple occasions is likely to be identified as a wife-beater. If 24 had used torture as a device to break the ticking timebomb deadlock on one occasion or perhaps twice throughout its six series, we would not necessarily diagnose a proattitude towards torture on the part of 24's creators. But 70 times in six series is too frequent to make plausible the equivalent excuse of 'I walked into a door/fell down the stairs'.

\section{Torture is necessary}

24 continually reinforces the message that torture is necessary (whether or not it is a necessary evil). When faced with the ticking time bomb scenario, or other shortness of time, one is required to torture.

This requirement, this necessity, is a practical necessity and, particularly when practised against (suspected) terrorists, a moral necessity. Time and time again, characters, especially Jack Bauer, are portrayed as being backed into a corner by circumstances, the only solution to which is torture.

And no one is safe. In Season Four, the Secretary of Defence orders the torture of his own teenage son by sensory deprivation, in order to make him reveal the names of his associates, who, it was feared, had used information he had innocently 
disclosed in order to kidnap the Secretary and his daughter. Later in the same series, the daughter of the Secretary of Defence, Audrey, is herself subject to intimidating interrogation by Jack (who is her lover), and then pharmaceutical torture by Burke of CTU, in order to reveal information about the same terrorists who had earlier kidnapped her and threatened her life. (Happily, Jack discovers that the information CTU possesses about Audrey - which mandated the decision to interrogate and torture her - has been planted by another of their prisoners. He holds a gun to this woman's head and threatens to kill her, until she confesses that the evidence implicating Audrey is a fabrication.)

Joel Surnow, co-creator and executive producer of 24 , has said this about fighting terrorism: ' $[\mathrm{t}]$ here are not a lot of measures short of extreme measures that will get it done'. ${ }^{22}$ Could he have stated his view more plainly?

\section{Torture is valuable}

24 assures us that not only is torture necessary; it is valuable. It yields useful information, the majority of the time (though sometimes a suspect will die before confessing). ${ }^{23}$ There are rare instances where a terrorist will endure torture rather than reveal a plot, but even this unusual stoicism can be overcome, as in the case of Sayyid Ali in the second series. Jack beats him, breaks his hands, and threatens unbearable pain, none of which measures is successful. Eventually, Jack stages the fake execution of Ali's wife and children, shown to Ali via a remote satellite link. When Ali's son is 'killed', he finally breaks, and reveals vital information about the nuclear bomb.

Tony Lagournais, former interrogator for the US Army in Iraq, told the show's creators:

In Iraq, I never saw pain produce intelligence... I worked with someone who used waterboarding... I used severe hypothermia, dogs, and sleep deprivation. I saw suspects after soldiers had gone into their homes and broken their bones, or made them sit on a Humvee's hot exhaust pipes until they got third degree burns. Nothing happened... [confessions] just told us what we already knew. It never opened up a stream of new information... physical pain can strengthen the resolve to clam up. ${ }^{24}$

In 2006, a letter and Statement on Interrogation Practices was sent by 20 former ${ }^{25}$ US army interrogators and interrogation technicians to the Committee on

Ibid.

See D. P. O'Mathúna, 'The Ethics of Torture in 24: Shockingly Banal' in J. Hart Weed, R. Davis and R. Weed, 24 and Philosophy (Oxford, Blackwell, 2008), pp 100-101 for a discussion of the efficacy and effects of torture.

Ibid., 5.

The names of interrogators on active duty were deliberately not included, in order to avoid open conflict with public statements by the US Secretary of Defense, his officials, and the Vice President and his office. 
the Armed Services. The interrogators included the Army's most senior interrogator at the time of his retirement, and veterans from conflicts ranging from Vietnam to Iraq. These documents denied that 'coercive interrogation techniques' and torture are necessary tools in the War on Terror, and in fact stated that 'experienced interrogators find prisoner/detainee abuse and torture to be counter-productive to the intelligence countering mission'. ${ }^{26}$

Interestingly, the statement itself uses the following phrasing: 'Prisoner/detainee abuse and torture are to be avoided at all costs, in part because they can degrade the intelligence collection efforts by interfering with the skilled interrogator's efforts to establish rapport with the subject'. ${ }^{27}$ This suggests that this instrumental reason is only one aspect of these seasoned interrogators' objections to torture.

\section{Torture is legally permissible}

The show gives the erroneous impression that torture is legally permissible, but this ignores both domestic provisions ${ }^{28}$ and international agreements (such as the UN Convention against torture) outlawing the use of torture. The only concession to the question of permissibility of torture in the course of duty are occasional references to internal CTU protocols on the limits on the use of pharmaceutical torture.

2:12 P.M. Buchanan shows Jack the toxicology reports on Graem. The coronary was caused by hyocine-pentothal used in the interrogation. The field reports show that Jack exceeded protocols, even after Burke warned him about the dangerous levels of serum. ${ }^{29}$

Yet despite having cavalierly ignored operational limitations, Jack is portrayed as a hero, not a criminal or a liability. Some oblique reference to the dubious nature of his intended actions can be inferred from the occasions on which Bauer resigns from CTU in order to remove procedural constraints from his actions. On one occasion, after discussing his planned illegitimate activities with the President, he resigns in order to ensure that the President has formal deniability.

\section{Heroes do torture as part of their duty}

The depiction of torture in 24 leads us to understand that Bauer takes no pleasure in inflicting pain; ${ }^{30}$ rather he does these unpleasant things, again and again, because it is necessary and dutiful.

P. Bauer, et al., Statement on Interrogation Practices 31 July 2006. Available online:

$<\mathrm{http}: / /$ www.amnestyusa.org/denounce_torture/statement_on_interrogation.pdf $>$ (accessed 10 November 2007).

27 Ibid. (emphasis added).

28 However controversially interpreted - see la Torre, Ch. 1 above.

29 Fox, Series 6, Episode Guide. 
For US army Brigadier General Patrick Finnegan, one of the military experts who protested to the creators of 24 about its pernicious effect on American soldiers, this equation of torture and duty is particularly distressing: 'the disturbing thing is that although torture may cause Jack Bauer some angst, it is always the patriotic thing to do. 31

This message of 24's resonates with the words of Dick Cheney, speaking shortly after the terrorist attacks of 9/11:

We also have to work, though, sort of the dark side, if you will. We've got to spend time in the shadows in the intelligence world. A lot of what needs to be done here will have to be done quietly, without any discussion, using sources and methods that are available to our intelligence agencies, if we're going to be successful. That's the world these folks operating in, and so it's going to be vital for us to use any means at our disposal, basically, to achieve our objective. ${ }^{32}$

Joel Surnow, co-creator and executive producer, puts it this way:

Isn't it obvious that if there was a nuke in New York City that was about to blow - or any other city in this country - that, even if you were going to go to jail, it [torture] would be the right thing to do?

And

America wants the war on terror fought by Jack Bauer. He's a patriot. ${ }^{33}$

Surnow also claims that soldiers in Iraq and personnel in the Bush administration are partial to the show: 'it's a patriotic show. They should love it' ${ }^{34}$ Cannily, this juxtaposition of torture and duty makes those who protest about Jack's actions not just weak, but also - one of the greatest of American sins - unpatriotic.

\section{What differentiates heroes and villains?}

There is little differentiation between heroes and villains in terms of their actions. ${ }^{35}$ It seems that the main thing that marks Jack and his colleagues apart from the terrorists is the nature of their goal: Jack et al want to save CTU/Los Angeles/the USA: the terrorists desire to destroy CTU/Los Angeles/the USA. Yet without any independent means of weighing the relative worth of these opposing goals, the series is left with nothing more than a conventional prejudice in favour of the US, or its

Cf. T. Morris, 'Philosophy? If you don't know 24, you don't know Jack' in J. Hart Weed, R. Davis and R. Weed, 24 and Philosophy (Oxford, Blackwell, 2008).

31 Mayer, 'Whatever it Takes', p. 4.

32 T. Russert, NBC News' Meet The Press: interview with Dick Cheney. Available online: http://www.fromthewilderness.com/timeline/2001/meetthepress091601.html (accessed 10 November 2007).

33 Mayer, 'Whatever it Takes', p. 2.

34 Ibid., p. 1.

35 The lines are blurred still further in Series 6 with a sadistic CTU agent, Doyle. 
power. It would be overly simplistic to say that 24 promotes the idea that might is right. However in all of the series, it tends to be the case at the mightier (the US) is more right than its opponents.

VII. Torture doesn't have serious (physical or psychological) consequences

Jack Bauer is almost superhuman in his ability to rise from the dead (literally, in one scene in which his heart was stopped by electrocution), or recuperate from less lethal damage, for example athletically escaping Fayed and his men after being tortured, and carrying on with active duties even whilst suffering from fragmented ribs in Series 6.

His colleagues also display remarkable fortitude. Two examples taken from the same series provide a brief snapshot. Morris, after having a steel bit power-drilled into his shoulder in order to compel him to do a task for some terrorists, returns to CTU and work at a computer. The only ill effect he seems to suffer is the impetus to start drinking alcohol again. Men are not the only heroes: Nadia, after suffering credible and frightening threats from her sadistic co-worker, Doyle, returns to work (and shortly afterwards even takes the role of Acting Director). Far from resenting or fearing Doyle, she seems to feel gratitude to him later in the programme.

These examples seem to suggest a rather flippant attitude on the creators' parts, denying the real aftermath of torture. This is the corollary to the 'sane and somewhat sanitized ${ }^{36}$ presentation of torture on 24 .

VIII. The ticking timebomb situation is a real threat to the US

Mayer quotes Bob Cochran, one of the show's co-creators, saying 'most terrorism experts will tell you that the 'ticking time bomb' situation never occurs in real life, or very rarely. But on our show it happens every week'. ${ }^{37}$ The sympathetic presentation of Bauer and CTU's mission has been described as 'a weekly rationalization of the 'ticking timebomb' defence of torture'. ${ }^{38}$

The Association for the Prevention of Torture describes the ticking time bomb scenario in the following terms:

[It] operates by manipulating the emotional reactions of the audience. It creates a context of fear and anger. It artificially tilts the circumstances to evoke sympathy or even admiration for the torturer, and hatred or indifference towards a torture victim...

36 O'Mathúna, 'The Ethics of Torture in 24', p.99.

37 Mayer, 'Whatever it Takes', p. 1.

38 J. Poniewozik, 'The Evolution of Jack Bauer' 14 January 2007. Available online: $<$ http://www.time.com/time/magazine/article/0,9171,1576853,00.html > (accessed 8 November 2007). 
[T] he intended effect of the ticking bomb scenario is to create a doubt about the wisdom of the absolute prohibition of torture. This doubt, in turn, is usually designed to lead the audience to accept the creation of legal exception to that prohibition, or at least to accept non-application of the criminal law against torture in particular cases. The true aim of proponents of the ticking bomb argument may be to create a broad exception while seeming to argue for a narrow one. By trying to force torture opponents to concede that torture may be acceptable in at least one extreme case, proponents of the ticking bomb argument hope to undermine the very idea that opposition to torture must be absolute as a matter of principle and practice. As such, the scenario has been given prominence lately by those who seek to end the taboo against torture, to make its application to prisoners suspected of involvement in terrorism seem acceptable, and to provide legal immunity for themselves and others who authorise, tolerate, order, or inflict it. ${ }^{39}$

What does it say about the goals and political sympathies of the show's creator(s) that they repeatedly portray the ticking time bomb scenario as real, with the concomitant message that torture is necessary to frustrate these attacks?

\section{These messages are unambiguous}

There are occasional points in the programme at which the acceptability of torture might be thought to be questioned. For example, in the most recent series, Jack loses his nerve: there is a moment when he took can no longer force himself to 'do what is necessary.'

Bauer has been returned to the US after 18 months of secret detention and ceaseless torture in China (he was captured at the end of Series 5). However, his return is not to safety: Jack learns that his superiors and the President have agreed to exchange him for a wanted terrorist, Assad, believed to be planning an imminent attack on the US. The compatriot who is betraying Assad wants to possess Jack Bauer in order to exact revenge for some encounter in their mutual past in Beirut. Bauer, whilst accepting with stoicism that it is legitimate for the President to use him as a pawn, to trade his life in order to thwart a major terrorist attack (accepting the universalization of the principle he lives by), manages to escape.

In one of the plot twists characteristic of the series, Assad turns out to be a sympathetic character, now resolved on peaceful political action, and it is in fact his compatriot Fayed who is planning the terror attack.

Bauer discovers that there is a mole within Assad's organization, who may have information the US security services need. He pursues this spy. An hour and a half into Series 6, Bauer has the spy in his power; circumstances require Bauer to extract information from the terrorist spy by inserting a knife into his open wound:

7:35 A.M. Jack aggravates Omar's open wound but Omar claims to be unaware where Fayed is. Suddenly, Jack stops. He is oddly reluctant to inflict any more pain on the man. This 
uncharacteristically disturbs him. He tells the puzzled Assad that he could see it in Omar's eyes that he wasn't going to talk.

7:36 A.M. Assad sticks his knife into Omar, who gives up that he knows where Fayed's men are going to meet. After Omar gives him the address, Assad kills him. Assad goes to leave but Jack is frozen. 'I don't know how to do this anymore,' Jack whispers. ${ }^{40}$

Jack is so traumatized by this and other happenings at the beginning of the latest series (he was 'forced' to shoot and kill Curtis, his colleague, in order to protect Assad) that he resigns from CTU.

However at 9:58 a.m., Fayed's group detonates a nuclear bomb in Los Angeles. Jack's qualms are dissolved by the impetus to do his duty, which in this case involves torturing his own brother (who has been implicated in the supply of the nuclear weapons), just under an hour later:

10:56 A.M. Jack slugs Graem and knocks him out. He ties Graem up in a chair. Jack grabs him by the throat and threatens to hurt him if he doesn't give up information. Graem says he is already hurting him. 'Trust me, I'm not,' Jack says intently. ${ }^{41}$

A few moments later, Jack suffocates his brother (non-fatally) with a plastic bag.

Jack's reluctance to torture the spy a few hours earlier is shown to be a momentary weakness, which is overcome when he comprehends the depravity of the terrorists. He is soon back on message after this epiphany: gung ho, efficient, and determined.

This is not the only occasion where opposition to its torture is shown to be weakness. In an earlier series, a suspected terrorist named Joe Prado is released from CTU just before interrogation, thanks to the efforts of a lawyer working for 'Amnesty Global', who had received an anonymous tipoff. Jack resigns from CTU in order to avoid implicating the organization in his actions. Prado is handcuffed in a parked car outside the CTU building. Jack enters the car, breaks Prado's hands, and is rewarded with crucial and accurate information. Earlier, the audience had been shown that Prado's lawyer's tipoff came from a terrorist source. This undoubtedly accentuated the predominant message of that storyline: 'regardless of good intentions, those seeking to protect suspects' rights risk abetting terrorist activities, to catastrophic ends. ${ }^{42}$

The pro-torture message of the series is unambiguous. Any derogation from the position that 'torture is a necessity; it is my duty to torture' is shown to be frailty: psychological or political weakness; rather than a reasonable and rational position to take.

40 Fox, Season Six Episode Guide.

41 Ibid.

42 A. Green, "Normalising Torture on "24", New York Times 22 May 2005. Available online: $<$ http:/www.nytimes.com/2005/05/22/arts/television/22gree.html?_r=1\&oref=slogin\&pagew anted $=$ print $>$ (accessed 12 November 2007). 
In the counterterrorist world of ' 24, '...torture represents not the breakdown of a just society, but the turning point - at times even the starting point - for social relations. Through this artistic sleight of hand, the show makes torture appear normal. $^{43}$

\section{E. Intention(s) of the programme makers}

What meaning do the programme-makers aim to convey?

\section{One message?}

A complicating factor is that different people are involved in various aspects of the creation of the programme. The writers on the show are described by Surnow as a mixture of liberals and conservatives. ${ }^{44}$

Squarely on the conservative side is Joel Surnow, co-creator and executive producer, and as such most clearly the author of the show.

Surnow is quoted as saying that the series is

'... ripped out of the Zeitgeist of what people's fears are - their paranoia that we're going to be attacked... [it] makes people look at what we're dealing with... ${ }^{45}$

Suzanne Fields, in the Washington Times, reports Surnow to have said 'Every American wishes we had someone out there neatly taking care of business'. She relates his response to a question - whether he would show waterboarding as one of the techniques used to produce a confession - 'Yes...But only with bottled water this is Hollywood'. ${ }^{46}$ This response in isolation might simply be viewed as tasteless, but Surnow clearly isn't joking about justice and heroism when he discusses the character, Jack Bauer: 'There's nothing left but to do the right thing... He's come to symbolize this sort of pure killing machine that all of us secretly want to unleash on the bad guys... [Bauer] really represents just justice'. ${ }^{47}$

And, as he told The Washington Times,

Ibid.

44 A. Cusac, 'Watching Torture in Prime Time' The Progressive, August (2005). Available online: <http://www.progressive.org/?q=mag_cusac0805> (accessed 12 November 2007). Mayer, 'Whatever it Takes', p. 2

46 S. Fields, 'Tortured by compromise' Washington Times 15 October 2007. Available online: $<$ http://www.washingtontimes.com/apps/pbcs.dll/article?AID=/20071015/EDITORIAL02/11 0150006\&template $=$ printart $>($ accessed 12 November 2007$)$.

47 R. S. McCain, " 24 " producer: Hilary as president is "nuts" Washington Times, 11 November 2007. Available online: <http://www.washingtontimes.com/apps/pbcs.dll/article? $\mathrm{AID}=/ 20071111 /$ NATION/71111001/-1/RSS_NATION_POLITICS\&template=printart $>$ (accessed 12 November 2007). 
'[i]f there's a bomb about to hit a major U.S. city and you have a person with information . . . if you don't torture that person, that would be one of the most immoral acts you could imagine. $^{, 48}$

Surnow is reported to have said that 24 does not 'try to push an agenda,' but is 'committed to being non-PC'. ${ }^{49}$ It is unlikely that many readers would accept a commitment to being 'non-PC', with all of the negative connotations a conservative such as Surnow places on 'being PC', as a neutral position. But even if it were, Duncan Kennedy could have told Surnow that a commitment not to act ideologically is in itself an ideological position. ${ }^{50}$

Bob Cochran, co-creator with Surnow (and a law graduate), is reported by Jane Mayer in The New Yorker to have said that he:

...supports the use of torture 'in narrow circumstances' and believes that it can be justified under the Constitution' [in the case of necessity, i.e. ticking timebomb]. ${ }^{51}$

So here, we can clearly see that the two most important individuals driving the series - whose imagination and inspiration provides the overarching flavour of the show - accept torture, at least in ticking time-bomb situations. And perhaps unsurprisingly, this is the message one derives from 24.

\section{II. 'Just entertainment'}

On the liberal flank of the writing team is Howard Gordon, who describes himself as a moderate Democrat. He also writes many of the torture scenes. He is concerned when:

'...critics say that we've enabled and reflected the public's appetite for torture. Nobody wants to be the handmaid to a relaxed policy that accepts torture as a legitimate means of interrogation... I think people can differentiate between a television show and reality'. ${ }^{52}$

This is frequently the cry of those who are involved in 24 and don't support torture - it's just a television show; it's just entertainment; it's not real.

One of the most vocal proponents of this view is Kiefer Sutherland, the actor who plays Jack Bauer, who in addition to being executive producer of the show, is leftwing and anti-torture.

In a TV interview with Charlie Rose, he is reported to have said:

'Do I personally believe that the police or any of these other legal agencies that are working for this government should be entitled to interrogate people and do the things that I do on the show? No, I do not ${ }^{53}$

48 Cusac 'Watching Torture'.

49 Ibid.

50 D. Kennedy, A Critique of Adjudication (Cambridge (Massachusetts), Harvard University Press, 1998).

51 Mayer, 'Whatever it Takes', p. 4.

52 Mayer, 'Whatever it Takes', p. 3. 


\section{In People News, Sutherland said:}

' 24 ' is absolutely not - categorically not - a justification for torture. I think the whole thing has been taken out of context. We are interested this has become a debate on a very public level. That's what is fantastic about entertainment - it brings certain subjects into people's conversations...'We are a television show, we use some of the torture sequences as a dramatic device to heighten tension. We are not saying, 'This is the way the world should be, and we are condoning this. ${ }^{54}$

On the other hand, there is the following description by David Danzig, a project director at Human Rights First, of an encounter between interrogators visiting the set of 24 and Kiefer Sutherland:

Sutherland was 'really upset, really intense' and stressed that he tries to tell people that the show 'is just entertainment'. But Sutherland, who claimed to be bored with playing torture scenes, admitted that he worried about the 'unintended consequences of the show'. ${ }^{5}$

\section{The true message - more than mere entertainment}

O'Mathúna argues that 'the banality of torture in 24 should shock us into realising how easily and quickly torture becomes acceptable. ${ }^{56}$ However, I argue that the effect on the viewer is not shock, but acceptance. In 24 , there is a constant, dramatically unchallenged repetition of the message that torture is necessary; valuable; morally (and legally) permissible; that a hero has the duty to torture; that America is under constant ticking time bomb threat. The way the programme is constructed, with action taking place against the clock; the repeated recourse to torture as 'the only option available', required in the circumstances (averaging 13 instances of torture per series); the fact that the torturer-in-chief is the 'hero' with whom we are meant to identify and sympathize - all these things are much more than 'mere entertainment'. The eminently watchable - what some people call 'addictive' - nature of the content makes the ideological message more powerful. ${ }^{57}$

These qualities convince me that 24 is more than merely entertainment with a right-wing slant. Certain characteristics of the series are more than amusement and rather akin to propaganda. For present purposes, we can borrow the OED's definition of propaganda as 'the systematic dissemination of information, esp. in a biased or misleading way, in order to promote a political cause or point of view. Also: information disseminated in this way; the means or media by which such ideas

Cusac 'Watching Torture'.

54 People News 'Kiefer Sutherland's 24 Defense' 18 March 2007. Available online: $<$ http://people.monstersandcritics.com/news/article_1279058.php/Kiefer_Sutherlands_24_ defense $>$ (accessed 12 November 2007).

55 Mayer, 'Whatever it Takes', p. 5.

56 O'Mathúna, 'The Ethics of Torture in 24', p.103.

57 See also S. Žižek, 'The depraved heroes of 24 are the Himmlers of Hollywood', The Guardian, 10 January 2006. 
are disseminated'. Specifically in 24, there is a repeated and systematic dissemination of material which favours the cause of a particular right-wing, protorture viewpoint. This may or may not be consciously done by (all) the show's creators, but the utterances of Joel Surnow, co-creater and executive producer of 24, suggest that thoughtlessness at least is not one of the factors in his part of the show's gestation.

Even if we accept that the express intention of 24 is to entertain, we may believe that the meaning of the programme goes further, giving it an altogether different, and worrying, significance. It is therefore neecessary to identify what this more extensive message might be.

\section{F. Subordination and Silencing}

The question of more extensive messages is precisely the point considerd by Rae Langton in the context of pornography. She discusses whether there may come a point at which the speech of one person subordinates and silences another, depriving them of effective speech, and reflects on the two feminist claims - often regarded as confused or problematic - that pornography, in addition to depicting subordination and causing subordination, is itself a form of subordination, and that it silences women. I explore her arguments before applying them to the context of torture in 24 .

\section{Subordination}

In her examination of pornography as subordination, she draws on J. L. Austin's categorization of words as 'speech acts' in How to Do Things with Words. ${ }^{58}$ If a first man tells a second man to shoot the woman standing next to them (and the second man does so), the act of uttering 'shoot her' is the performance of a locutionary act the utterance of a sentence with a particular meaning. But this does not exhaust the description of the scene. Additionally, part of the perlocutionary act involved is the shock generated by such an utterance; as is the persuasive effect of saying 'shoot her'. ${ }^{59}$ And this is still not a comprehensive description:

... if you stop there you will still have left something out. You will have ignored what our first man did it saying what he said. So you go on. In saying 'shoot her', the first man urged the second to shoot the woman. That description captures the action constituted by the utterance itself: it captures what Austin called the illocutionary act. $^{60}$

58 R. Langton, 'Speech Acts and Unspeakable Acts' Philosophy and Public Affairs 22, no. 4 (1993): 293-330, p. 295 et seq.

59 Ibid.

60 Ibid., pp. 295-296. 
Austin's account of this additional dimension of speech acts encompasses the idea that speech has some kind of illocutionary power when certain 'felicity conditions' are satisfied, usually specified by written or unwritten conventions, which characteristically require intention on the part of the speaker. ${ }^{61}$ Examples Langton gives of such illocutionary acts include warning, promising, and marrying.

However, as a type of action, speech acts suffer from the same weaknesses as action in general: sometimes we do something other than that which we aimed to do - the recipient of our speech may have understood our words as an order rather than advice, for example. Alternatively, the intended illocution may simply fail. ${ }^{62}$

Langton considers that Catherine MacKinnon's claim ${ }^{63}$ that speech can subordinate makes sense if the illocutionary aspect of speech is taken into account, in addition to locution and perlocution. In the context of pornography, its illocutionary force is subordination. ${ }^{64}$

Where subordinating speech is uttered by someone in power (for example 'Blacks are not permitted to vote' said by a legislator enacting legislation which underpins apartheid), ${ }^{65}$ the illocutionary power of the utterance

... unfairly ranks blacks as having inferior worth; they legitimate discriminatory behaviour on the part of whites; and they unjustly deprive them of some important powers.

...Actions of ranking, valuing and placing are illocutions... labelled verdictive by Austin. ${ }^{66}$

Other types of illocutions - those which order, permit, prohibit, authorize, enact, or dismiss - may confer on or deprive of powers and rights. These are called exercitive by Austin. Crucial to both these types of illocution is the fact that the speaker is in a position of authority (formal or practical), which gives such speech a power it would otherwise lack. ${ }^{67}$

Can it correctly be said that pornographic speech acts have the authority needed to be verdictive, without which they cannot subordinate women? After all, pornographers tend not to be legislators, statesman, etc. Langton considers that

what is important here is not whether the speech of pornographers is universally held in high esteem: it is not - hence the common assumption among liberals that in defending pornographers they are defending the underdog. What is important is whether it is authoritative in the domain that counts - the domain of speech about sex - and whether it is authoritative for the hearers that count: people, men, boys, who in addition to wanting 'entertainment,' want to discover the right way to do things, want to know which moves in the sexual game are legitimate. What is important is whether it is authoritative for those hearers

61 Ibid., p. 301.

62 Ibid., pp. 301-302.

63 C. MacKinnon, 'Francis Biddle's Sister' in Feminism Unmodified (Cambridge

(Massachusetts), Harvard University Press, 1987), p. 176, as cited in Langton, 'Speech Acts', p. 294 , n. 2.

64 R. Langton, 'Speech Acts', p. 302.

65 Langton, 'Speech Acts', p. 302.

66 Ibid., p. 304.

67 Ibid., pp. 304-305. 
who - one way or another - do seem to learn that silence is sexy and coercion legitimate... in this domain, and for these hearers, it may be that pornography has all the authority of a monopoly. ${ }^{68}$

Authority, then, may be practical and subjective, rather than formal, and need not follow the conventional social order.

\section{Silencing}

Langton proffers a threefold classification of silencing that corresponds to Austin's scheme. First, persons or a group may be literally silent due to intimidation or hopelessness. Here, they do not perform even a locutionary act. Second, despite speaking, the group or persons will fall short of their intended goal - their perlocutionary act has been frustrated, for example when one's vote for a particular party is part of the minority. The third silencing goes to the heart of the illocutionary action intended:

... one speaks, one utters words, and fails not simply to achieve the effect one aims at, but fails to perform the very action one intends. Here, speech misfires... Silencing of this third kind we can call illocutionary disablement.... ${ }^{69}$

Not having authority in a relevant field may constitute illocutionary disablement. ${ }^{70}$ This kind of silencing, in Langton's terms, has made the actor's speech unspeakable. Langton goes on to consider instances of illocutionary disablement in the context of pornography, and concludes that pornography may silence women by making it impossible for them to achieve the effect they wish to achieve - for example, if one of pornography's messages is that sexual violence is permissible, it is a corollary that pornography may prevent a woman's genuine refusal of sex from being taken seriously: 'the felicity conditions for refusal, for protest, are not being met. Something is robbing the speech of its intended force'. ${ }^{71}$ What is preventing a woman's refusal from being understood in this type of case?

For Langton, the diagnosis is stark:

The felicity conditions for women's speech acts are set by the speech acts of pornography. The words of the pornographer, like the words of the legislator, are 'words that set conditions.' they are words that constrain, that make certain actions - refusal, protest - unspeakable for women in some contexts. ${ }^{72}$

Whilst pornography does not usually prevent women from uttering words at all (performing locutionary acts), Langton wishes us to take very seriously the claim that pornography literally silences. If women are merely able to use words, but not

Ibid., p. 312

69 Ibid., p. 315.

70 Ibid., p. 316.

71 Ibid., p. 323.

72 Ibid., p. 324. 
achieve their aim - if the illocutionary import of an utterance has been neutralized or disabled, they fail to perform a speech act.

On Austin's view, locutions on their own are nothing. Locutions are there to be used. Words are tools. Words are for doing things with. There is little point in giving someone tools if they cannot do things with them. And there is little point in allowing women words if we cannot do things with them. That, at any rate, is not free speech. ${ }^{73}$

\section{24 as speech acts}

Having set out Langton's analysis, we can now consider whether 24 contains an important illocutionary message.

In 24 , the locutionary aspect of the torture scenes, the 'speech act' in question, is the depiction of torture. The effect this depiction has on viewers - including the potential encouragement of torture as an interrogation method in real life - would be a perlocutionary aspect of the series' speech acts. What illocutionary message might the programme hold?

To misquote Langton: ${ }^{74}$ not all explicit depictions of torture promote torture. Locutions that depict torture could in principle be used to perform speech acts that are a far cry from torture promotion: documentaries, for example, or investigative reports, or government studies, or books that protest against torture, or perhaps even legal definitions of torture. It all depends, as Austin might have said, on the use to which the locution is put.

What does 24 do in its depiction of torture? In repeatedly portraying torture as necessary, valuable, legally and morally permissible, and the proper remit of the hero, the series urges both the public and the interrogator to accept torture as a good tool, and to disregard any qualms we may have about its legitimacy and efficacy, and the subordination and dehumanization of any person suspected of terrorism. This is 24 's illocutionary aspect.

Again, substituting ' 24 ' and the theme of 'torture' for Langton's references to pornography: ${ }^{75}$ torture promotion is first, verdictive speech that ranks victims as inferiors, and second, exercitive speech that legitimizes violence interrogation. Since torture is not simply harm, not simply crime, but discriminatory behaviour, torture promotion subordinates because it legitimizes misbehaviour... for these two reasons, then, 24 is an illocutionary act of subordination.

The verdicts in its message are unfair, giving undue weight to one side of the argument; are discriminatory against anyone suspected of possible involvement in terror, and the illocutionary message of 24 unjustly deprives terror suspect of important safeguards. In its own world as well as the real, the verdictive force of 24

74 Ibid., pp. 305-306.

75 Ibid., pp. 307-308. 
is also exercitive, as those suspected of terrorism are deprived of power and rights, and those suspecting terrorism are permitted frightening latitude in their interrogations.

A television show that depicted positive messages of torture in a debate about diverse interpretations of 'right action' and different criteria of morality would not have this illocutionary force. Debate is valuable in its own right; not least to expose the weaknesses of any argument. The existence of alternative, credible points of view would negate the overwhelmingness of one illocutionary message, and undermine the verdictive power of one standpoint. But in 24, there is no debate. Any divergence from the orthodox message is quickly portrayed as pathetic and insubstantial. The verdictive illocutionary effect remains.

How important is this illocutionary message? If we agree that 24 has a pro torture message that subordinates the interests of anyone suspected (reasonably or not) of terrorism, is this a real cause for concern? The answer to this question depends on whether the verdictive and exercitive messages of 24 are taken seriously by its recipients. In other words, does 24 have practical, subjective authority for (at least a significant part of) its audience?

Before addressing this, we need to pause to deal with one potential objection: it might be thought, when referring back to my three sets of circumstances in the context of information dissemination, above, that I am attempting some sleight of hand. Why is the subjective authority of the speaker important, when I have already stated that the intention of the recipient of (torture) information cannot make a publication immoral? However, in that instance, I was referring to situations where the publication or dissemination of information about torture is either morally permissible or required. This present discussion relates to practical considerations in the instance where the intention of the publisher is (at least arguably) impermissible.

Joel Surnow, as principal creator of 24 , has broadcast his views on torture and legitimate interrogation quite extensively. As the creator and director of a popular television series, and the personality in his own right, he may be seen as authoritative person for at least some of 24's audience. However, I suspect that the principal person giving voice to the speech acts of 24 is someone else: Jack Bauer.

Jack's views are, unsurprisingly, coextensive with his creator Surnow's. Jack is the hero, the man who always does the right thing, the character with whom we are invited to identify and for whom we are expected to feel admiration. When we suspend our critical faculties and enjoy the entertainment on offer, the internal logic of the series makes eminent sense, and we, too, feel that Jack has no real option but to torture, even with the most slender grounds for suspicion of a particular individual. Kiefer Sutherland's contribution to this message is the way in which he convinces the audience that his character is admirable rather than abhorrent.

Is it implausible to think that interrogators who want to discover the right way to do things, want to know which moves in the interrogation game are legitimate, may use 24 as their guide? It is reported that Sutherland agreed to talk to cadets at West Point military academy, at the invitation of the US military, in order to teach recruits 
that torture is wrong. ${ }^{76}$ Sutherland's commitment indicates that he thinks that this is at least plausible.

Is it not possible that the illocutionary message of 24 has contributed to the illocutionary disablement of suspects in the war on terror? It seems that there is at the least the danger of illocutionary disablement. If we accept that pornography may make women's protests unspeakable, we should be concerned that 24 may silence victims of torture and other interrogation abuses by making it impossible for them to achieve the effect they wish to achieve; by frustrating the felicity conditions for the arguments against it.

But it is important not to overstate the case against 24. Although the TV series sends a message that purports to have authority and is plausibly subjectively received as such, and does seem to have had some very regrettable effects on the actions of soldiers, ${ }^{77}$ it is not the only culprit. Nor is the popularity of 24 , although extensive, comparable with the pervasiveness of pornography and other means of subordinating women.

Moreover, my objection is not simply that 24 sends an immoral illocutionary message. I object to the context in which it does so.

\section{Propaganda, lies and disguise}

24 is not simply entertainment. 24 is a vehicle with a pervasive ideological message. It is propaganda.

Propaganda generally involves some element of persuasion, if not deception. ${ }^{78}$ We may agree that deception is prima facie wrong, but I doubt that many people would claim that deception is always wrong. There may be circumstances in which the purposes of a lie justify its telling: where the wrong done is outweighed on the moral scales. Examples might include lying to the victim of a car accident about the extent of their injuries, with the intention of inculcating hope and therefore promoting survival, or disseminating untruthfully positive information about Allied military successes during World War II, to avoid despair and therefore defeat. ${ }^{79}$

In this chapter, I have assumed, rather than established, that torture is morally wrong. If we continue to accept this, we may be willing to categorize the message of 24 as an untruth, relevantly similar to the factual untruths in the above scenarios. As such, it it would be prima facie wrong.

Perhaps we may consider that telling lies about the permissibility and efficacy of torture is justifiable in some circumstances. If so, it may be possible to generate an

77 See e.g., P.Sands, 'Stress, hooding, noise, nudity, dogs' The Guardian 19 April 2008.

78 Cf. Paul Taylor's neutral definition of progaganda: P.M.Taylor, 'Perception Management and the "war" against terrorism' Journal of Information Warfare 1(3) (2002): 16-29.

'Information warfare' as per Taylor. Ibid. 
argument that justifies the broadcasting of 24. I am unable to think of one, it is true but even my outrage at the wrong of telling lies about torture does not seem to exhaust the iniquity of 24 .

Let us consider another scenario: an alternative show, with similarly entertaining storylines, but which promoted a (stereo)typically liberal position in a comparably repetitive, simplistic, didactic and authoritative manner.

Per series, this imaginary show (working title 9 Months) depicts an average of 13 instances of abortion, because:

- it is the right thing to do;

- it's what a woman needs to do in those circumstances;

and

- any squeamishness on the part of those involved needs to be overridden, because it is their duty to choose/perform abortions;

- in the face of the imminent threat of population explosion/global warming/food shortages, abortion is what's necessary.

Would Surnow, and 24's creative team be satisfied with the excuse that 9 Months is just entertainment'? Rightly, I suspect they would not. The verdictive, illocutionary aspect of such a show would shift the programme outside the category of mere entertainment - as is the case with 24 .

But the 'just entertainment' excuse is not simply an inaccurate description of such a programme. 'Just entertainment' is part of 24's disguise.

24 is propaganda by virtue of its illocutionary force. Moreover, it is surreptitious propaganda which masquerades as entertainment; whose existence is 'justified' as entertainment. Its very existence as a television programme is a lie, irrespective of its ideological content. Here, we have a double lie: content and concealment.

Moreover, 24 stealthily, seductively convinces us that torture is a serious option, in fact a necessary, mandatory and inevitable right response to suspicion and time pressure and the need for information, and does so in the guise of entertainment.

\section{G. Conclusion}

The programme 24 is immoral in its exclusively pro-torture message, which has a disturbingly verdictive force, and in the way this message masquerades as entertainment.

Torturers deny the humanity of their victims. Torturers violate our most important moral and societal norms. 24 violates these standards, in the name of entertainment, and it also abuses the norms of entertainment. It is part of the poison of the programme that we are persuaded to suspend disbelief and witness repeated 
inflictions of extreme physical or mental violence. To return to my third point about the intention of the recipient: we suspend our humanity by watching uncritically. 